Int. J. Environ. Res. Public Health 2004, 1(2), 111-123

\title{
Freshwater Microcosms-Based Assessment of Eco-toxicological Effects of a Chemical Effluent from the Pilcam Industry in Cameroon
}

\author{
A. Monkiedje ${ }^{1 *}$, T. Njine ${ }^{1}$, A. L. Meyabeme Elono ${ }^{1}$, S. H. Zebaze ${ }^{1}$, N. Kemka ${ }^{1}$, P. B. Tchounwou ${ }^{2}$, and J. E. Djomo ${ }^{3}$ \\ ${ }^{1}$ Laboratory of General Biology, Department of Animal Biology and Physiology, Faculty of Science, University of \\ Yaounde I, P.O. Box 812, Cameroon \\ ${ }^{2}$ Molecular Toxicology Research Laboratory, NIH-Center for Environmental Health, College of Science, Engineering and \\ Technology, Jackson State University, 1400 Lynch Street, P.O. Box 18540, Jackson, Mississippi, USA. \\ ${ }^{3}$ Laboratory of Animal Biology, University of Dschang, Cameroon \\ *Correspondence to Dr Adolphe Monkiedje. E-mail: monkiedje@yahoo.com
}

Received: 28 January 2004 / Accepted: 16 June 2004 / Published: 30 September 2004

\begin{abstract}
We studied the acute toxicity of a raw effluent from a battery manufacturing plant (Pilcam) in Douala, Cameroon, to a freshwater fish (Oreochromis niloticus), and subsequently evaluated its sub-acute effects on water quality and the biota in freshwater microscosms. The acute toxicity test was based on $96 \mathrm{hrs}$ static renewal bioassays that resulted in $96-\mathrm{h} \mathrm{LC}_{50}$ and $\mathrm{LC}_{90}$ values of 16 and $20.7 \%(\mathrm{v} / \mathrm{v})$, respectively. The sub-acute experiments were conducted by exposing several species of aquatic organisms (plankton, macroinvertebrates and mollusks) to lower effluent concentrations $[1.6 \%, 8.0 \%, 16 \%(\mathrm{v} / \mathrm{v})]$ for six weeks, and monitoring their survival rates, as well as the physical and chemical characteristics of water. These concentrations were based on $10 \%, 50 \%$, and $100 \%$ of the $96 \mathrm{~h}$ - median lethal concentrations $\left(\mathrm{LC}_{50}\right)$ of the effluent to the freshwater fish, Oreochromis niloticus. Significant effects on functional parameters, such as, chlorophyll-a and total protein could not be demonstrated. However, the activity of alkaline phosphatase was significantly inhibited at all concentrations tested. Phytoplankton, zooplankton, macro-invertebrate communities and snails were negatively affected by the effluent application at concentrations $\geq 8 \%(\mathrm{v} / \mathrm{v})$, with chlorophyta, ciliates, ostracoda, annelida, planaria and snails being the most sensitive groups. The snails were eliminated after $24 \mathrm{~h}$ exposure from microcosms treated with effluent at concentration $\geq 8 \%(\mathrm{v} / \mathrm{v})$. Effluent exposure also caused significant effects on water quality parameters (DO, $\mathrm{pH}$, hardness, conductivity, color, turbidity, ammonia) in general at concentrations $\geq 8 \%(\mathrm{v} / \mathrm{v})$. Temperature and alkalinity were not significantly affected. Overall, data from this research indicate that a dilution of the Pilcam effluent down to $1.6 \%$ does not provide protection against chronic toxicity to aquatic organisms. Further studies are needed to determine the no observable adverse effect level (NOAEL), as well as a chronic reference concentration for this effluent.
\end{abstract}

Keywords: Industrial chemical effluent, aquatic microcosm, ecotoxicological effects, water quality

\section{Introduction}

Cameroon is located along the end of the West side of West African Coast of the Gulf of Guinea in the Atlantic Ocean. The portion of the Gulf of Guinea which is under Cameroon's territorial waters has the most diverse and productive ecosystems. The country's coastline is $402 \mathrm{~km}$ long and extends from the Rio del Rey Estuary at the boundary with the Federal Republic of Nigeria, and to the Kribi coast along the boundaries with Equatorial Guinea and Gabon. It is the major sink for discharge of pesticides and persistent organic pollutants (POPs) by inland rivers that drain into the Atlantic Ocean. The region has the most industrialized areas of the country, high population density, as well as accounting for about $80 \%$ of the national annual GDP. A traditional meal in this area includes fish foods. About $39 \%$ of the population in this zone has an annual average 
consumption of $7.02 \mathrm{~kg}$ of fish harvested from the Atlantic Ocean.

About 95\% of Cameroon's industries including the battery production factory (Pilcam) lie along the coastal town of Douala, the economic capital and most populous town in Cameroon. Most of these industries discharge their liquid wastes (often without treatment) into the urban drainage network which in turn empties its content into the Atlantic Ocean. Of these industries, less than $10 \%$ have on-site waste water treatment facilities, and those that own such facilities operate under different standards. The main contributors to environmental pollution from these industrial wastes include heavy metals, pesticides and polychlorinated biphenyls (PCBs) which are persistent and have high potential to bioaccumulate in the food chain.

The production of batteries in Pilcam generates very toxic liquid waste containing heavy metals such lead, cadmium, mercury, zinc, copper and chromium [1, 2]. Cadmium causes necrosis and chlorosis in aquatic organisms. It is lethal to plankton at $2 \mu \mathrm{g} / \mathrm{l}$. Aquatic invertebrates seem to resist more to the toxic effects of this element than fish [3].The bio-accumulation of lead in crayfish Palaemon elegans induces a significant depletion of red blood cells [4]. Bacteria transform mercury into toxic and less biodegradable methyl mercury that bio-accumulates in the food chain $[1,5,6$, 7]. Mercury interferes with the respiratory function in mollusks and crustaceans [8]. High levels of zinc in water suffocate fish, following the destruction of the gill epithelium [3,5]. In mollusks and crustaceans, lethal and sub-lethal levels of zinc have been reported to cause an internal development of hypoxia that blocks respiration [8]. Several studies have shown that there has been a steady increase in the destruction of marine life (decreasing fish and mangroves population, in particular), due to pollution from the sources cited above [9]. Microbial communities and aquatic organisms tested in laboratory microcosms have previously shown sensitivities to several toxic compounds at environmentally realistic levels [10-16].

In this research, we evaluated the acute toxicity of a raw effluent from a battery manufacturing plant (Pilcam) in Douala, Cameroon, to a freshwater fish (Oreochromis niloticus), and subsequently studied its sub-acute effects on water quality and the biota in freshwater microscosms. Both taxonomic (phytoplankton and protozoan species richness and composition and macroinvertebrates communities and snails) and non taxonomic (biomass, stored material and enzyme activity) responses were measured.

\section{Materials and Methods}

Juvenile Oreochromis niloticus measuring $5.33 \pm 0.64$ $\mathrm{cm}$ and weighing $2.50 \pm 1.10 \mathrm{~g}$ were collected from the Yaounde Municipal Lake. They were acclimatized to laboratory conditions in all-glass aquaria $(150 \mathrm{~cm} \times 70 \mathrm{~cm}$ $\mathrm{x} 60 \mathrm{~cm}$ ) for four weeks prior to experimentation. The aquaria were supplied with aerated spring water (temperature $24.1 \pm 0.2^{\circ} \mathrm{C}$; total hardness $62.0 \pm 1 \mathrm{mg} / \mathrm{l}$ as $\mathrm{CaCO}_{3} ; \mathrm{pH} 6.20 \pm 0.02$; alkalinity $75.0 \pm 0.6 \mathrm{mg} / \mathrm{l}$ as $\mathrm{CaCO}_{3} ; \mathrm{NH}_{3}-\mathrm{N}$ and total residual chlorine were below the detection limits of $20 \mu \mathrm{g} / \mathrm{l}$ and $5 \mu \mathrm{g} / \mathrm{l}$, respectively).

A composite sample of the raw chemical industrial effluent was collected from its discharge pipe in the urban drainage network and transported to the laboratory. This sample (601 in polyethylene cans) was obtained by mixing proportionally to their flow rates. Grab samples (mean flow rate $26 \mathrm{~m}^{3} / \mathrm{d}$ ) were collected every 15 minutes for 6 hrs representing a working shift period at the factory. The physico-chemical properties of this raw effluent included temperature $=24.1 \pm 0.2{ }^{\circ} \mathrm{C}$; salinity $=0.70 \pm 0.05 \%$ total hardness $=164.0 \pm 0.5 \mathrm{mg} / 1$ as $\mathrm{CaCO}_{3} ; \mathrm{pH}=5.15 \pm 0.02$; conductivity $=1926 \pm 3$ $\mu \mathrm{S} / \mathrm{cm}$; and total suspended solids $=965 \pm 2 \mathrm{mg} / \mathrm{l}$. Its heavy metals content was not evaluated.

The acute toxicity tests were conducted according to Standard Methods [17] and EPA methods for staticrenewal acute toxicity tests [18]. Five test concentrations (dilutions) of the effluent and a control were used. Each effluent concentration was tested in duplicate and the experiments were repeated once to evaluate variability and the average values of toxic end-points determined.

The $\mathrm{LC}_{50}$ and $\mathrm{LC}_{90}$ were estimated using the U.S. EPA probit analysis computer program version 1.3 used for calculating effective concentrations written by C. Stephen of the Duluth U.S. Environmental Protection Agency's Environmental Research Laboratory.

Sub-acute concentrations of the raw effluent $[1.6 \%$, $8.0 \%, 16 \%(\mathrm{v} / \mathrm{v})]$ were used in subsequent freshwater microcosms studies. These test concentrations were respectively $10 \%, 50 \%$ and $100 \%$ of the $96-\mathrm{h}$ median lethal concentration $\left(\mathrm{LC}_{50}\right)$ obtained from the test fish (Oreochromis niloticus).

Laboratory microcosm's experiments were conducted in glass microcosms $(60 \times 30 \times 35 \mathrm{~cm})$. Exposure medium was natural water collected from the pelagic zone of the Yaounde Municipal Lake, using a small ZODIAC boat model MR II GR. The average temperature, $\mathrm{pH}$, dissolved oxygen, harness, alkalinity, conductivity and total dissolved solids (TDS) of the water were $24.07^{\circ} \mathrm{C}, 7.12$, $5.13 \mathrm{mg} / \mathrm{l}, 70 \mathrm{mg} \mathrm{CaCO}_{3} / \mathrm{l}, 245 \mu \mathrm{s} / \mathrm{cm}$ and $164.7 \mathrm{mg} / \mathrm{l}$, respectively. A total of 401 of medium were added to each of the 4 microcosms.

The test organisms for these microcosms' experiments included the natural microbial and benthic macroinvertebrate communities obtained by filtering $(<64 \mu \mathrm{m}$ plankton net) lake water from the pelagic and herbarium littoral zone, respectively. Five liters of filtrate were added to each microcosm. Snails of Lymnea, Bulinus, Physa, and Biomphalaria genera were also added to each microcosm. The microcosms thus constituted were allowed to acclimate to laboratory conditions for 3 weeks. The water loss by evaporation in microcosms was compensated by adding distilled water. The composition of these 
microcosms in terms of organisms prior to the experiment is shown in Table 1.

The experiment consisted of 6-weeks of exposure and monitoring. The microcosms were dosed with a single application of raw effluent at the nominal concentrations of $0,1.6,8.0$ and $16 \%(\mathrm{v} / \mathrm{v})$. Sampling was done every $24 \mathrm{~h}$ for the first 4 days, the seventh day, and subsequently every 7 days until the end of the experiment. Microcosms were lighted with daylight-equivalent bulbs (Color Rendering Index $>90$; Durotest, Corp.) at an intensity of approximately 5000 lux on a $16 \mathrm{~h} / 8 \mathrm{~h}$ of light/dark photoperiod. Temperature was uncontrolled and fluctuated with ambient laboratory temperature $\left(25-27^{\circ} \mathrm{C}\right)$.

The physical and chemical conditions monitored included microcosms temperature, $\mathrm{pH}$, alkalinity, color, total suspended solids, dissolved oxygen, turbidity, ammonia-N, total hardness, and conductivity. Microbial biomass accumulated in microcosms after each exposure period was estimated by measuring total protein. An aliquot of each sample was concentrated by gentle centrifugation (1000 rpm for 10 minutes). Aliquots of resulting residues were extracted using $0.5 \mathrm{~N} \mathrm{NaOH}$ [19] and protein analyzed by the method of Bradford [20]. Aliquots of each sample residues were also analyzed for chlorophyll a [17] and alkaline phosphatase activity [21].

Protozoan and phytoplankton densities and species richness within the microbial communities were used as an indicator of community complexity, since it was not feasible to identify all microbial species present. The size and the number of protozoan species in each sample were determined within $6 \mathrm{~h}$ of collection by microscope examination [22]. Samples for phytoplankton density and species distribution were collected and preserved with acid Lugol's. Organisms were concentrated in settling chambers and counted using a Wild inverted microscope. Distribution changes of species were recorded from counts of one sample per microcosm at detection limits of 23 organisms per $\mathrm{ml}$ [23].

Plankton species in each sample were assigned to a taxa group to identify any major compositional shifts (e.g the disappearance of taxa). Most protozoan species fell within four major groups (rotifer, ciliates, copepoda, and ostracoda), whereas phytoplankton species fell within three (cyanophyta, chromophyta and chlorophyta). Therefore, only these taxa groups were used in subsequent analyses.

Benthic macro-invertebrates were also examined, and assigned to a taxonomic group to identify differences in sensitivity to the effluent. These benthic organisms were distributed in groups including annelids, planaria and nematodes. The number of living organisms in each taxa was recorded after each exposure period.

\section{Data Analysis}

Table 1 showed that the biota composition (density and specific richness) varied from one microcosm to another. Consequently, all results were expressed in terms of percent of the initial level [(level at $t /$ level at $\left.t_{0}\right) x$ 100] and were presented in histograms using software Excel version 5.0. The mean values of water quality parameters of the untreated and treated microcosms were compared using the paired Student $t$ test from the Systat software version 5.0

\section{Results and Discussion}

\section{Effect of Pilcam Effluent on Fish}

The acute toxicity of the effluent to fish (Oreochromis niloticus) is shown in Table 2. The 48-h $\mathrm{LC}_{50}$ and 48hLC90 for Oreochromis niloticus were $20.8 \%$ (v/v) and $26.6 \%(\mathrm{v} / \mathrm{v})$ of effluent respectively, whereas the $96-\mathrm{h} \mathrm{LC}_{50}$ and $96-\mathrm{h} \mathrm{LC}_{90}$ values were $16 \%(\mathrm{v} / \mathrm{v})$ and $20.7 \%(\mathrm{v} / \mathrm{v})$ respectively. These results show that Pilcam effluent exerts a high toxic effect on the freshwater fish Oreochromis niloticus. When exposed for $48 \mathrm{~h}$ and $96 \mathrm{~h}$ to a $14 \%(\mathrm{v} / \mathrm{v})$ diluted effluent, $0 \%$ and $30 \%$ fish kill were recorded respectively. When the percent dilution of the effluent was increased to $20 \%(\mathrm{v} / \mathrm{v})$, fish mortalities of $40 \%$ and $90 \%$ were obtained after $48 \mathrm{~h}$ and $96 \mathrm{~h}$ of exposure respectively.

As this effluent contains mostly heavy metals $(\mathrm{Hg}, \mathrm{Cd}$, $\mathrm{Pb}$, and $\mathrm{Zn}$ ) [1, 2], high levels of zinc in water were reported to suffocate fish by damaging the gill epithelium, thus blocking respiration [3, 5]. Mercury is probably the most serious metallic pollutant of the seas. In oxygenated marine sediments bacteria may convert the less toxic, inorganic form of the metal to the more toxic, organic form of methyl mercury. This chemical form is relatively mobile in the environment and tends to accumulate in fish. Some fish, such as tuna have naturally high levels which may approach or even exceed acceptable limits for human consumption in large, older specimens even without apparent adverse health effects in the fish [24].

Histopathological damages in Oreochomis niloticus exposed to petroleum refinery effluent containing $\mathrm{Pb}$, $\mathrm{Fe}, \mathrm{Zn}, \mathrm{Cd}, \mathrm{Cu}, \mathrm{Ni}$, and $\mathrm{Hg}$ have been reported [25]. This fish, collected from High Dam and Nasser lakes in Egypt has been shown to concentrate in its dorsal fins and liver high levels of lead, cadmium and zinc. Untreated industrial effluent from factories near Islamabad and containing $\mathrm{Pb}, \mathrm{Fe}, \mathrm{Zn}, \mathrm{Cd}, \mathrm{Cu}, \mathrm{Ni}$ and $\mathrm{Hg}$ caused $100 \%$ mortality in carp fishes exposed for 24 hours [26]..

\section{Effect of Pilcam Effluent on Microcosm Water Quality}

The mean values of the studied water quality parameters are shown in Table 3 . The variations of the temperature ranged from $98 \%$ to $106 \%$ of initial values in all microcosms during the study. The $\mathrm{pH}$ variations ranged between $80 \%$ and $130 \%$ of initial values with a significant increase in the 8.0 and $16.0 \%(\mathrm{v} / \mathrm{v})$ microcosms. Total alkalinity (as $\mathrm{CaCO}_{3}$ ) variations were in general small ranged between $96 \%$ and $108 \%$ of initial values in 
Table 1: Initial biota composition in microcosms $(\mathrm{t}=0$ day; $\mathrm{n}=$ number $)$

TAXA

MICROCOSM

Control $\quad 1.6 \% \quad 8 \% \quad 16 \%$

$(v / v) \quad(v / v) \quad(v / v\}$

\section{PHYTOPLANCTON (Cells/ml)}

CYANOPHYTA

Oscillatoria tenuis

Oscillatoria putrida

$\begin{array}{llll}105490 & 7988 & 58242 & 83876 \\ 308 & 50 & 142 & 98\end{array}$

\section{CHLOROPHYTA}

Monographidium contortum

Monographidium griffithii

Scenedesmus sp.

77
154
$/$

\section{CHROMOPHYTA}

Cyclotella meneghiniani

202
$/$
$/$

/ $\quad 308$

\section{ZOOPLANCTON (Cells /100ml)}

\section{CILIATES}

Strombidium gyrans

Coleps hirtus

Disematostoma sp.

Uronema sp.

Urocentrum turbo

Prorodon ovalis

Pleurotricha lanceolata

Litonotus sp.

Paramecium africanum

Euplotes amieti

Dileptus sp.

\section{ROTIFERS}

Dicranophorus caudatus

Brachionus angularis

Rotaria rotaria

Anureopsis fissa

Macrotrachella sp.

Asplanchna sp.

COPEPODA

OSTRACODA

BENTHIC MACRO-INVERTÉBRATES (n/100ml)

\section{PLANARIA}

NEMATODS

\section{ANNELIDS \\ Tubifex $\mathrm{sp}_{1}$.}

Tubifex $\mathrm{sp}_{2}$.

\section{SNAILS (n/ 40 liters )}

Lymnea sp.

Bulinus sp.

Physa sp.

Biomphalaria sp.

$\begin{array}{ll}77 & 98 \\ 1 & 1 \\ 2 & 9 \\ 5 & 3\end{array}$


Table 2: Experimental data from the acute toxicity test of Pilcam effluent on fish (Oreochromis niloticus)

\begin{tabular}{|c|c|c|c|}
\hline \multirow{2}{*}{ Effluent concentration $(\% v / v)$} & \multirow{2}{*}{ No. of fish exposed } & \multicolumn{2}{|c|}{ No. ${ }^{a}$ of fish dead at } \\
\hline & & $48 h$ & $96 h$ \\
\hline 20 & 20 & 8 & 18 \\
\hline 18 & 20 & 4 & 16 \\
\hline 16 & 20 & 4 & 12 \\
\hline 17 & 20 & 2 & 8 \\
\hline 14 & 20 & 0 & 6 \\
\hline 0 & 20 & 0 & 0 \\
\hline $\begin{array}{l}\mathrm{LC}_{50}(\% \mathrm{v} / \mathrm{v}) \text { estimated by } \\
\text { probit analysis. }\end{array}$ & & 20.8 & 16.0 \\
\hline $95 \%$ Confidence limits & & $18.9-49.8$ & $13.4-17.2$ \\
\hline $\begin{array}{l}\mathrm{LC}_{90}(\% \mathrm{v} / \mathrm{v}) \text { estimated by } \\
\text { probit analysis. }\end{array}$ & & 26.6 & 20.7 \\
\hline 95\% Confidence limits & & $21.9-237.2$ & $18.6-34.3$ \\
\hline Slope of probit line & & 12 & 11 \\
\hline
\end{tabular}

${ }^{\text {a }}$ Average number of 2 replicates

Table 3: Mean values of water quality parameters studied of control and treated microcosms with various concentrations of the effluent during the study (6 weeks of exposure)

\begin{tabular}{lcccc}
\hline & \multicolumn{3}{c}{ Effluent concentration $(\% \mathrm{v} / \mathrm{v})$} \\
\cline { 2 - 5 } Parameter & Control & 1.6 & 8.0 & 16.0 \\
\hline Temperature $\left({ }^{\circ} \mathrm{C}\right)$ & $24.24 \pm 1.79$ & $24.24 \pm 1.79$ & $24.23 \pm 1.87$ & $24.24 \pm 1.79$ \\
pH (Std Units) & $7.68 \pm 0.35$ & $7.39 \pm 0.48$ & $7.25 \pm 0.16^{*}$ & $6.93 \pm 0.68^{*}$ \\
Dissolved oxygen $(\mathrm{mg} / \mathrm{L})$ & $4.02 \pm 1.26$ & $3.86 \pm 1.17$ & $3.87 \pm 1.49^{*}$ & $3.45 \pm 1.23^{*}$ \\
Conductivity $(\mu \mathrm{S} / \mathrm{Cm})$ & $221.6 \pm 14.2$ & $255.4 \pm 9.7 *$ & $319.5 \pm 27.7^{*}$ & $392.3 \pm 60.2^{*}$ \\
TSS $(\mathrm{g} / \mathrm{L})$ & $87.4 \pm 50.6$ & $4.7 \pm 2.9$ & $51.1 \pm 32.3^{*}$ & $58.4 \pm 36.9^{*}$ \\
T. hardness $(\mathrm{mg} / \mathrm{L} \mathrm{as} \mathrm{CaCO})$ & $36.4 \pm 15.3$ & $30.9 \pm 5.0$ & $49.7 \pm 12.2$ & $61.5 \pm 17.3$ \\
T. alk. $(\mathrm{mg} / \mathrm{L} \mathrm{as} \mathrm{CaCO})$ & $69.5 \pm 24.0$ & $53.5 \pm 10.6$ & $70.5 \pm 11.3$ & $52.5 \pm 20.5$ \\
Turbidity $(\mathrm{FTU})$ & $89.7 \pm 43.9$ & $11.5 \pm 4.7$ & $50.6 \pm 29.6^{*}$ & $58.7 \pm 36.0^{*}$ \\
Colour $(\mathrm{PtCo})$ & $415.5 \pm 171.9$ & $63.7 \pm 22.1$ & $271.0 \pm 142.3^{*}$ & $299.6 \pm 152.6^{*}$ \\
Ammonia-N $(\mathrm{mg} / \mathrm{L})$ & $0.56 \pm 0.26$ & $0.08 \pm 0.03$ & $0.33 \pm 0.20^{*}$ & $0.41 \pm 0.25^{*}$ \\
Chlorophyll a $(\mu \mathrm{g} / \mathrm{mL})$ & $128.5 \pm 117.9$ & $172.1 \pm 176.0$ & $202.5 \pm 305.2$ & $55.8 \pm 136.9$ \\
Total protein $(\mu \mathrm{g} / \mathrm{mL})$ & $6.6 \pm 3.0$ & $4.3 \pm 1.8$ & $4.4 \pm 2.6$ & $1.8 \pm 1.4$ \\
Alk phos. $(\mu \mathrm{g} \mathrm{PNP} / \mathrm{mL} / \mathrm{h})$ & $0.1 \pm 0.1$ & $0.4 \pm 1.0^{*}$ & $0.4 \pm 1.3^{*}$ & $0.1 \pm 0.1^{*}$ \\
\hline
\end{tabular}

TSS: Total suspended solids; Alk phos: Alkaline phosphatase activity;

T. hardness: Total hardness; T. alk: Total alkalinity.

* Parameter with Effluent addition significantly different $(p<0.05)$ from no Effluent addition, using the paired 
microcosms, whereas the total hardness (as $\mathrm{CaCO}_{3}$ ) variations were irregular and ranged between $50 \%$ and $250 \%$ with a significant increase in $8 \%$ and $16 \%(\mathrm{v} / \mathrm{v})$ treated microcosms. The water remained highly mineralized in effluent treated microcosms with conductivity fluctuations ranging from $110 \%$ to $180 \%$ of its initial value. The total suspended solids generally decreased in all microcosms. It varied from $10 \%$ to $115 \%$ of its initial value with significant decrease in the 8 and $16 \%(\mathrm{v} / \mathrm{v})$ microcosms. The values of the apparent color and turbidity decreased in all microcosms. The color and turbidity ranged from $18 \%$ to $125 \%$ and $18 \%$ and $105 \%$ respectively of their initial values with significant decreased in the 8 and $16 \%(\mathrm{v} / \mathrm{v})$ microcosms.

The significant decrease of total suspended solids, apparent color and turbidity could be due to sedimentation and the reduction in organic loading due to fish kill. Dissolved oxygen ranged from 1.72 to $6.84 \mathrm{mg} / \mathrm{l}$ in all microcosms. It generally decreased in all microcosms during the first three weeks of exposure, probably due to the death of organisms and fouling of water. This decrease was significant in the $8 \%$ and $16 \%(\mathrm{v} / \mathrm{v})$ microcosms. This is in accordance with the findings that showed that the increase in heavy metals contents of seven study sites in coastal areas in Kuwait caused a depletion in dissolved oxygen [27]. Ammonia-N also significantly decreased ( $p<$ $0.05)$ in microcosms treated with $8 \%$ and $16 \%(\mathrm{v} / \mathrm{v})$ of effluent. Ammonia-N being the final major product of the protein catabolism excreted by aquatic animals [28], its significantly low excretion could be ascribed to the decrease of the density of organisms in these microcosms.

\section{Effect of Pilcam Effluent on the Plankton Community Function}

Chlorophyll a measures the biomass of autotrophic organisms accumulated in the microcosms. The chlorophyll-a of phytoplankton communities in the microcosms increased steadily during the first 4 days of exposure in all microcosms with some stimulation in all treated microcosms (up $1150 \%$ of initial value), and declined rapidly and remained low in all microcosms after 21 days of exposure. Based on the intrinsic variations of the chlorophyll-a content relative to initial value in each microcosm, the inhibitive effect of effluent on the photosynthesis could not be demonstrated (Fig.1).

Three days following the application of Pilcam effluent, microbial biomass (protein) in the $1.6 \%(\mathrm{v} / \mathrm{v})$ microcosm was increased while it slightly decreased in the $16 \%(\mathrm{v} / \mathrm{v})$ microcosm as illustrated in Fig. 1. After 4 days, the biomass generally tended to decrease with increasing effluent concentration and exposure time, but the effect was not significant $(p>0.05)$ over the entire exposure period.

The activity of alkaline phosphatase enzyme measures the rate of cleavage of phosphorus organic compounds by the microbial community. One day following the application of the effluent, the alkaline phosphatase activity significantly decreased in all treated microcosms relative to the untreated microcosm (Fig. 1). Of the parameters analyzed for the plankton community function, this parameter seemed to be the most sensitive to Pilcam effluent-induced stress.

\section{Effect of Pilcam Effluent on the Phytoplankton Structure}

Cyanophyta were the most abundant taxa and showed a global decrease in density throughout the experimentation. This decrease seemed more pronounced in 8 and $16 \%(\mathrm{v} / \mathrm{v})$ microcosms (Fig. 2). The density of chlorophyta was not regular with increasing exposure period. They disappeared completely from the $1.6 \%(\mathrm{v} / \mathrm{v})$ microcosm after 28 days of exposure, and from the 8 and $16 \%(\mathrm{v} / \mathrm{v})$ microcosms after 3 and 14 days of exposure, respectively (Fig. 2). The density of chromophyta moderately varied during the first week of exposure with a significant decrease in the 1.6\% $(\mathrm{v} / \mathrm{v})$ microcosm, and subsequently was eliminated from all microcosms as the fourteen day of exposure. In the control, an abrupt re-colonization of chromophyta was observed on the $42^{\text {nd }}$ day (Fig. 2). The species present in all microcosms and occasionally abundant in the $1.6 \%(\mathrm{v} / \mathrm{v})$ microcosm throughout the study were Planktothrix mougeotii and Oscillatoria putrida with putrida being more sensitive to the effluent toxicity than mougeotii.

The presence of cyanophyta in all microcosms throughout the study as compared to chlorophyta and chromophyta may indicate a probable resistance of this taxa to Pilcam effluent stress. This is consistent with reported findings showing that cyanobacteria are qualitatively and quantitatively predominant in the Godavari stream polluted by heavy metals [29]. This is also in accordance with the observation that cyanophyta are extremely opportunistic, and are able to bloom in disturbed ecosystems [30]. Moreover, the dominance of cyanophyta in various microcosms could also be attributed to the production of toxins that inhibit the growth of other algae, therefore promoting their own proliferation [31-32].

\section{Effect of Pilcam Effluent on the Zooplankton Structure}

After one day of exposure in $8 \%$ and $16 \%(\mathrm{v} / \mathrm{v})$ treated microcosms, protozoa density and species richness and composition significantly reduced relative to initial values and remained so for the remaining sampling periods (Fig. 3 and Fig. 4). The protozoan community structure in the $1.6 \%(\mathrm{v} / \mathrm{v})$ microcosm was affected gradually with some recovery for the ciliates density. The inhibitory effects of Pilcam effluent on zooplankton density and species richness in all treated microcosms at all sampling periods, were most obvious for ciliates and to some extent, rotifers ( $<28$ days) whose biomass shifts followed a concentration-response pattern expected for single species tests. Dominant ciliates species present in untreated and $1.6 \%(\mathrm{v} / \mathrm{v})$ 


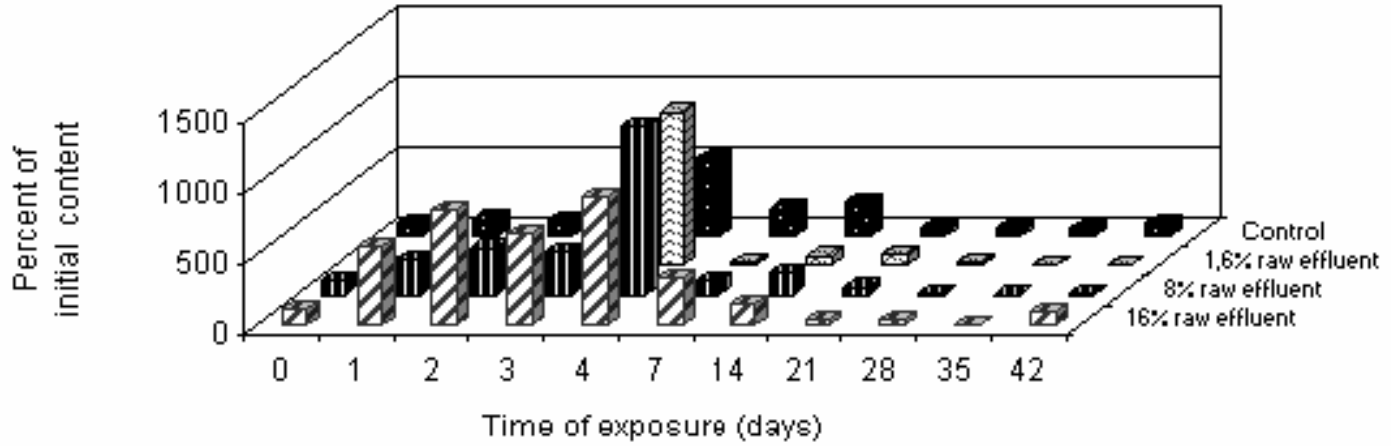

Chlorophyll A ( $\mu \mathrm{g} / \mathrm{mL})$

Initial content: Control $=80 ; 1.6 \%(\mathrm{WM})=42.7 ; 8 \%(\mathrm{WM})=96.1 ; 16 \%(\mathrm{VM})=61.1$

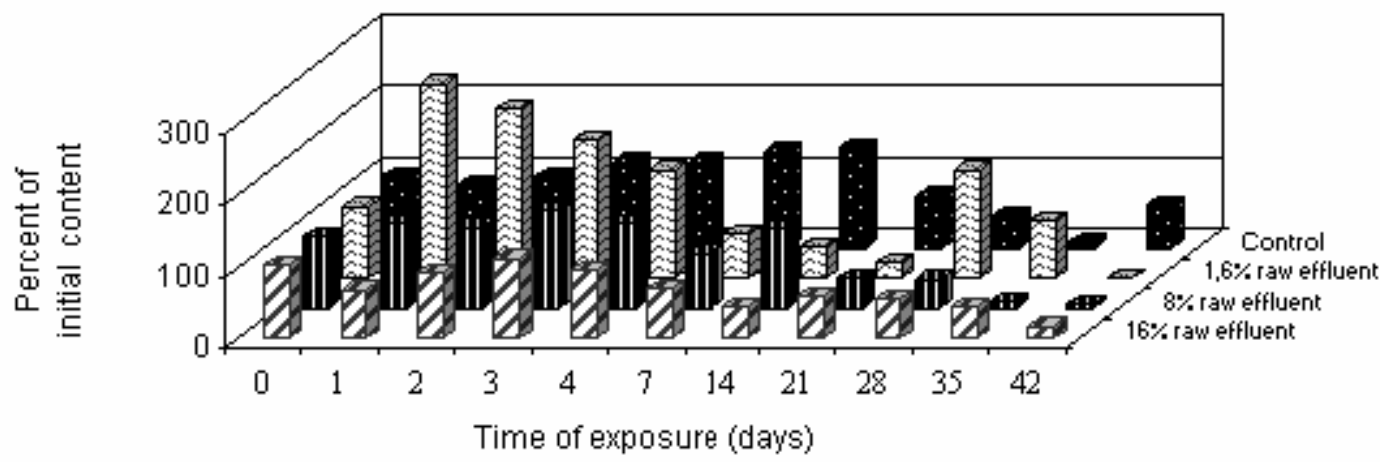

Total protein $(\mu \mathrm{g} / \mathrm{mL})$

Initial content: Control $=7 ; 3 ; 1.6 \%(\mathrm{~V})=1 ; 55 ; 8 \%(\mathrm{VM})=5.57 ; 16 \%(\mathrm{VM})=3.37$

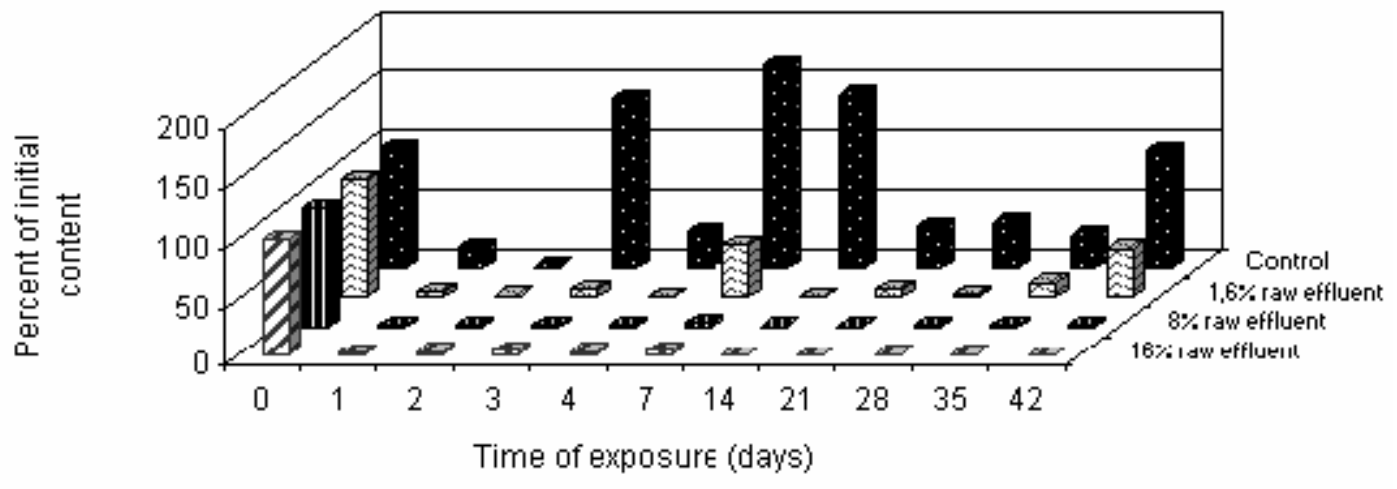

Alkaline phosphatase activity ( $\mu \mathrm{gPNP} / \mathrm{ml} / \mathrm{h})$

Initial content Control $=0.17 ; 1.6 \%(\mathrm{WM})=0.36 ; 8 \%(\mathrm{WM})=4.25 ; 16 \%(\mathrm{WM})=3.37$

Figure 1: The effect of Pilcam effluent on the chlorophyll A, microbial biomass (protein) content and alkaline phosphatase activity of untreated and treated microcosms. Significant effluent levels can be found in table 3 . 


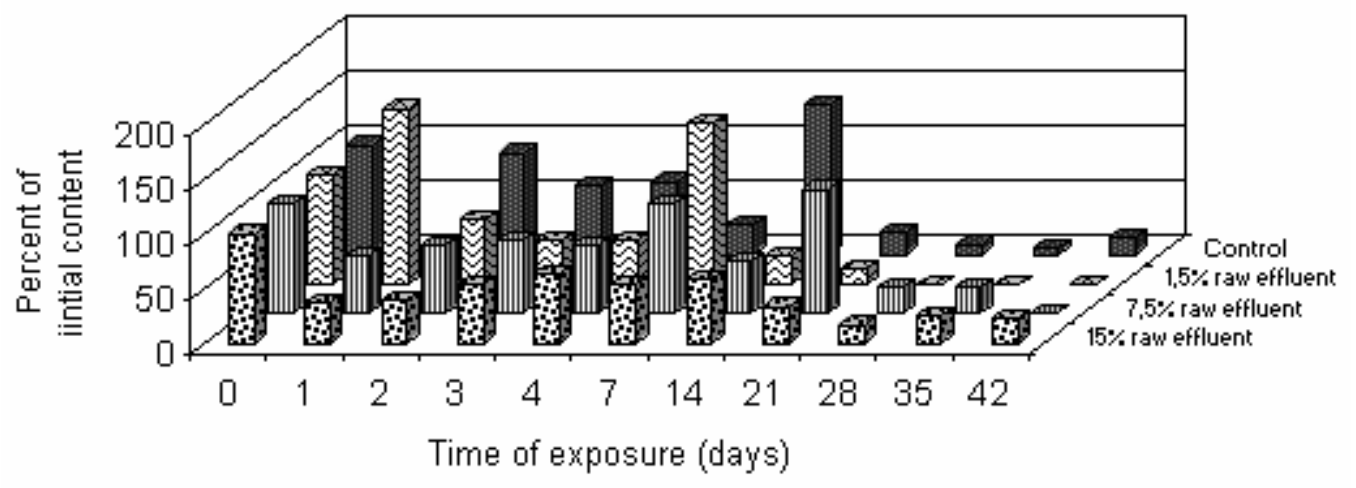

\section{Cyanophyta/mL}

initial content control $=105798 ; 1.6 \%(\mathrm{WM})=8038 ; 8 \%(\mathrm{WM})=58384$; $16 \%(\mathrm{M})=83974$

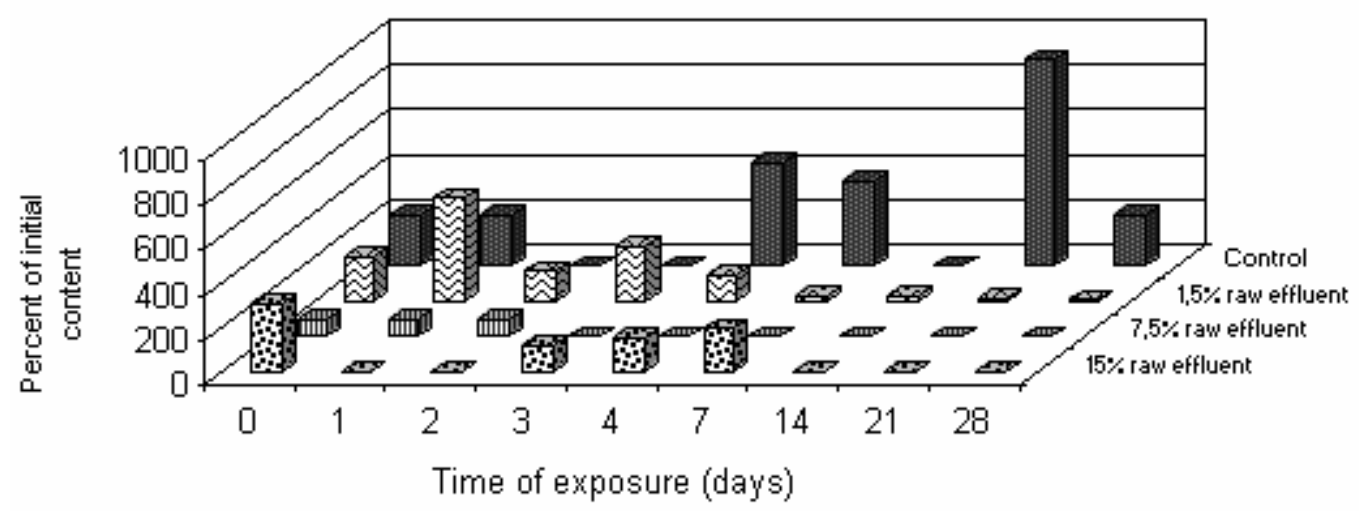

Chlorophyta/mL

Initial content: control $=231 ; 1.6 \%(\mathrm{VN})=202 ; 8 \%(\mathrm{VN})=77 ; 16 \%(\mathrm{VN})=308$

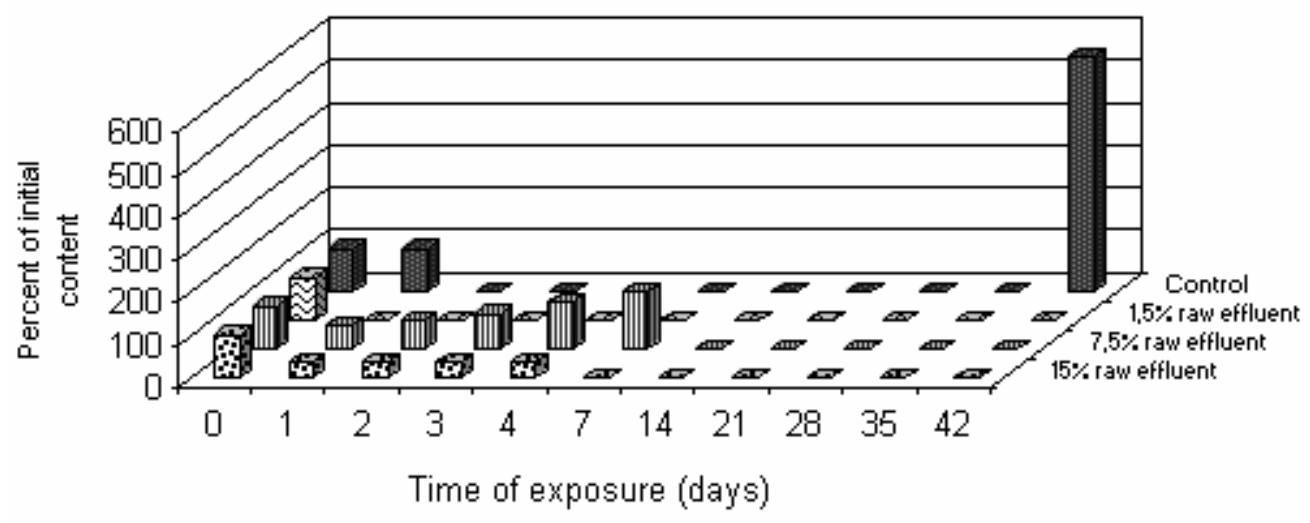

Chromophyta/mL

Initial content: control $=77 ; 1.6 \%(\mathrm{WM})=10 ; 8 \%(\mathrm{WN})=142 ; 16 \%(\mathrm{WM})=308$

Figure 2: The effect of Pilcam effluent on the phytoplancton density from untreated and treated microcosms 


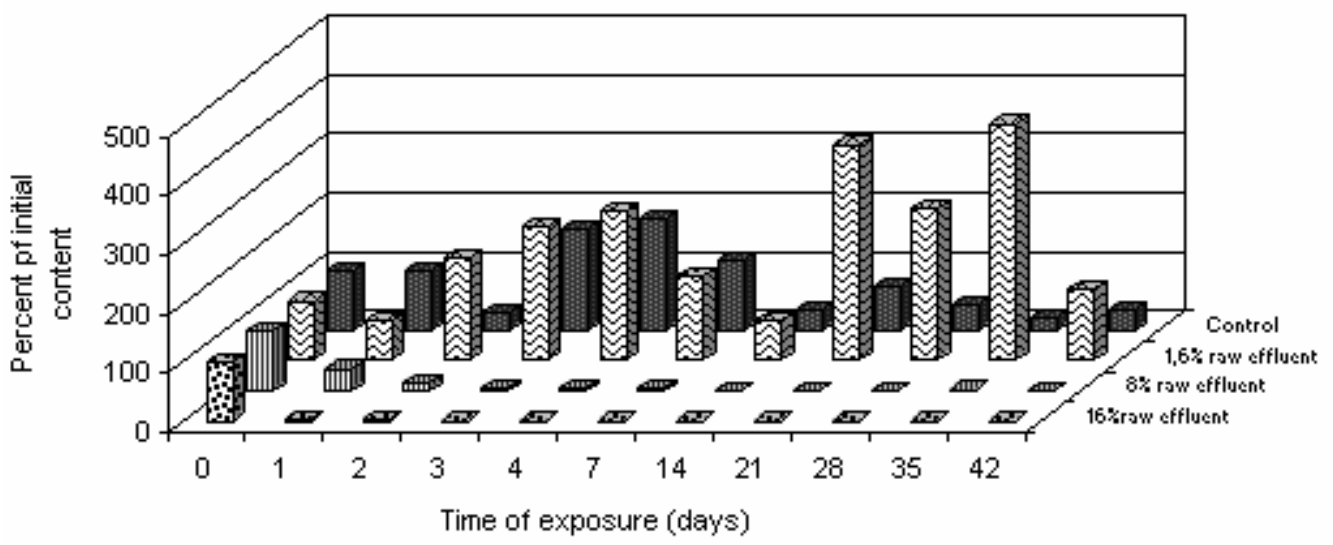

Ciliates $/ \mathrm{mL}$

Initial content: control=7150; $1.6 \%(\mathrm{~V} N)=1123 ; 8 \%(\mathrm{~V} N)=16691 ; 16 \%(\mathrm{~V} N)=13695$

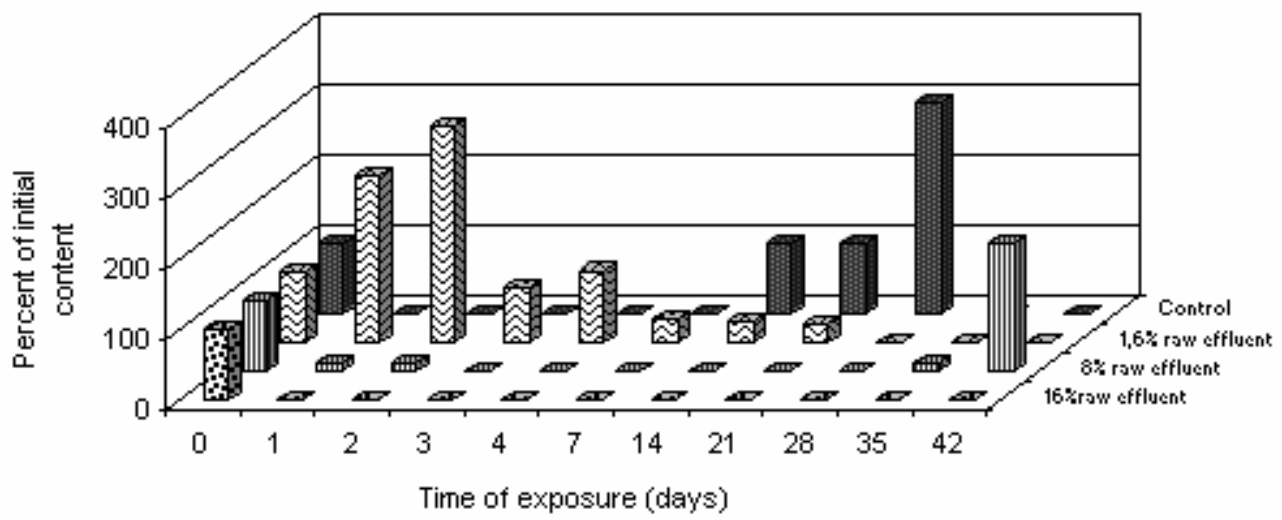

Rotifers/mL

Initial content: control $=25 ; 1.6 \%(\mathrm{~N})=98 ; 8 \%(\mathrm{~N})=207 ; 16 \%(\mathrm{~N})=191$

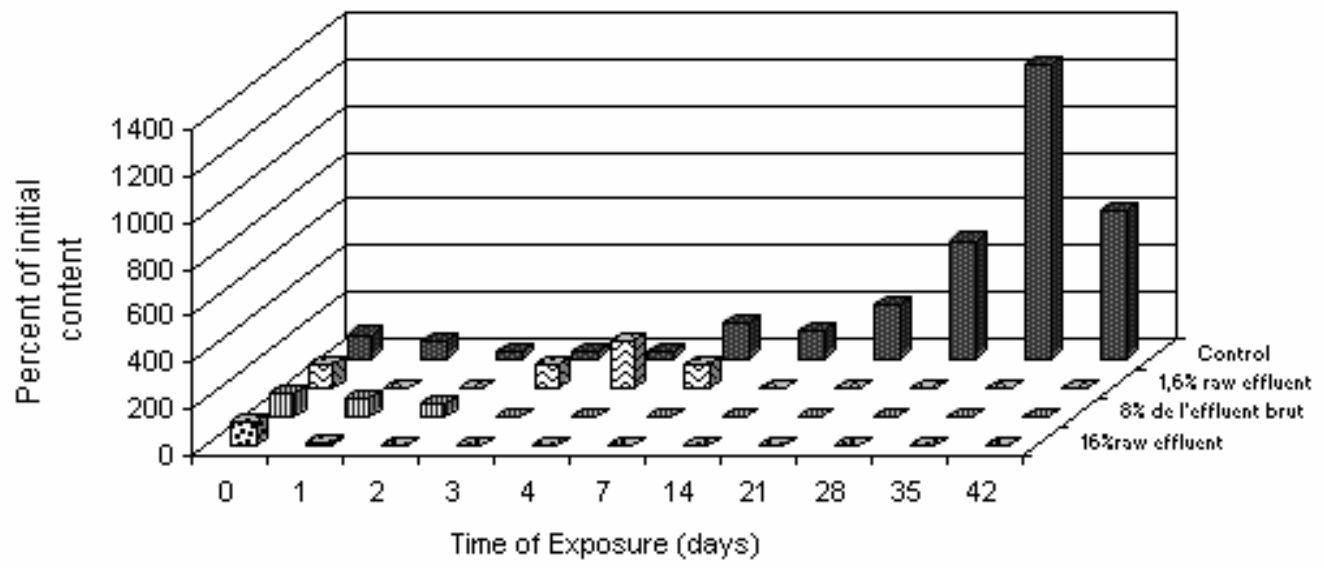

\section{Ostracoda/mL}

Initial content: controll: control=100;1.6\%(VN=0;8\%(VN=46;16\%(V) $=340$

Figure 3: The effect of Pilcam effluent on the protozoan density from untreated and treated microcosms 


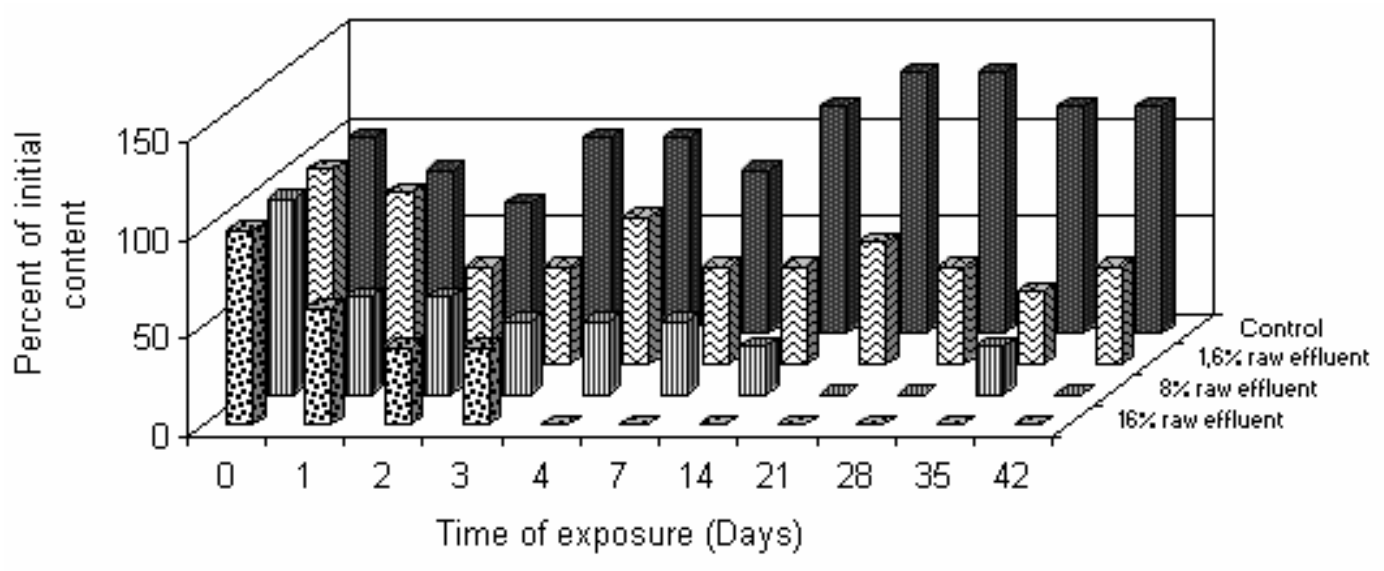

A: Number of Ciliates species $/ \mathrm{mL}$

Initial content: control=6; $1.6 \%(\mathrm{~V} N)=8 ; 8 \%(V \mathrm{~N})=8 ; 16 \%(\mathrm{~V})=5$

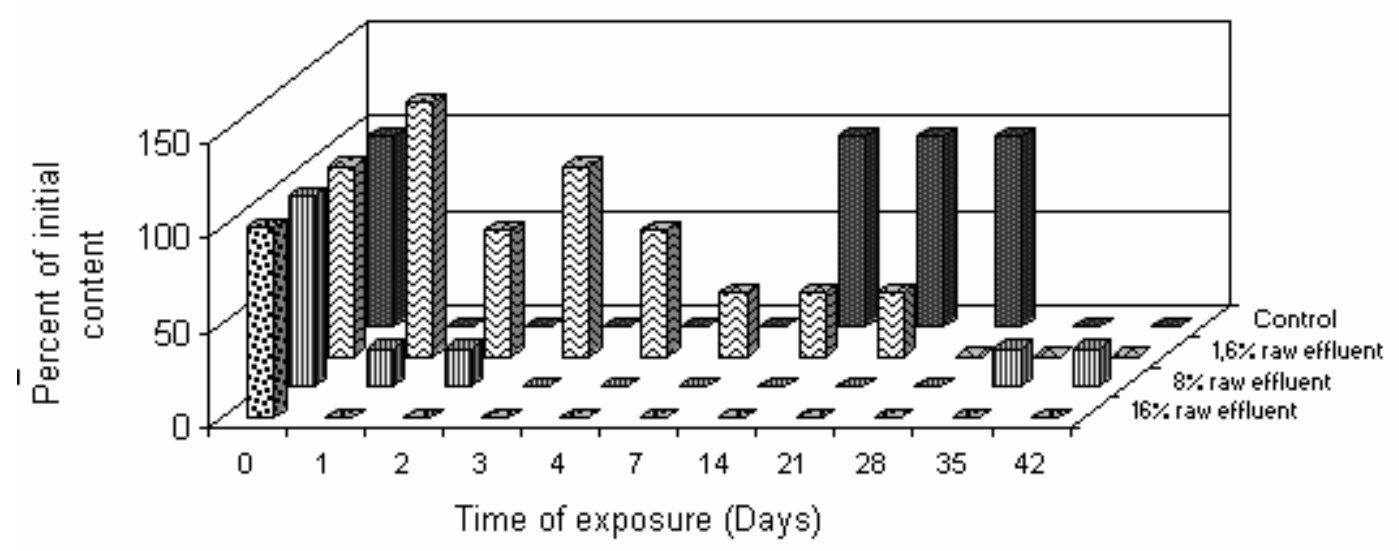

B: Number of Rotifer species/mL

Initial content: control=1; $1.6 \%(V N)=3 ; 8 \%(V N)=5 ; 16 \%(V N)=3$

Figure 4: The effect of Pilcam effluent on the protozoan species (A: Ciliates; and B: Rotifers) richness and composition from microcosms 


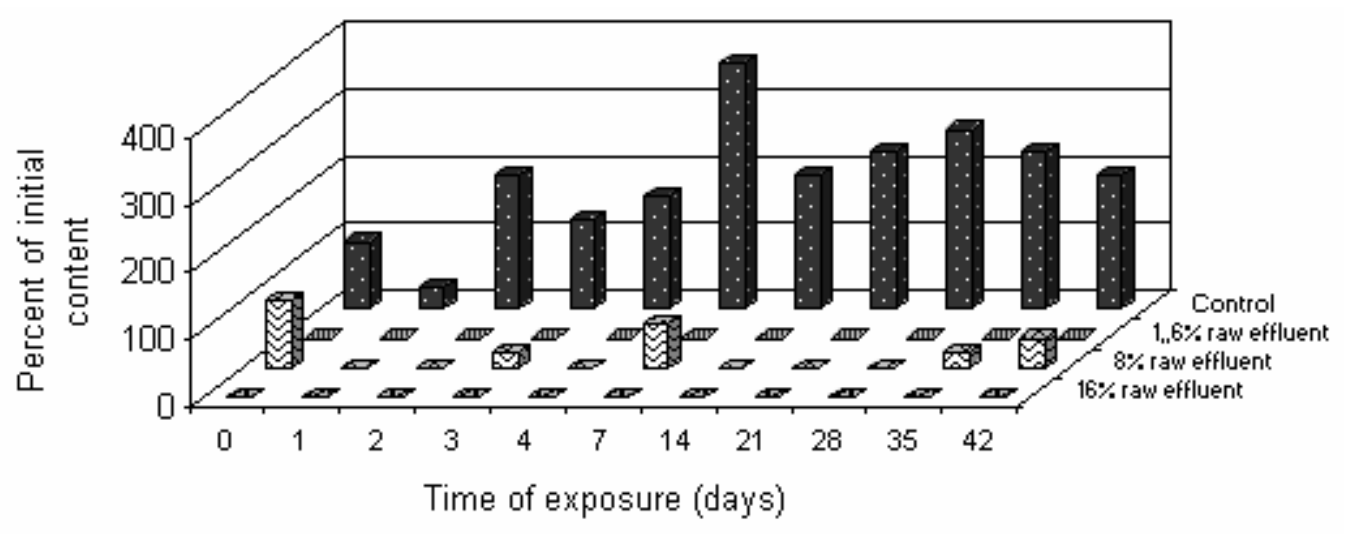

Nematoda/mL

Initial content: control $=75 ; 1.6 \%(\mathrm{VN})=0 ; 8 \%(\mathrm{VN})=116 ; 16 \%(\mathrm{VN})=0$

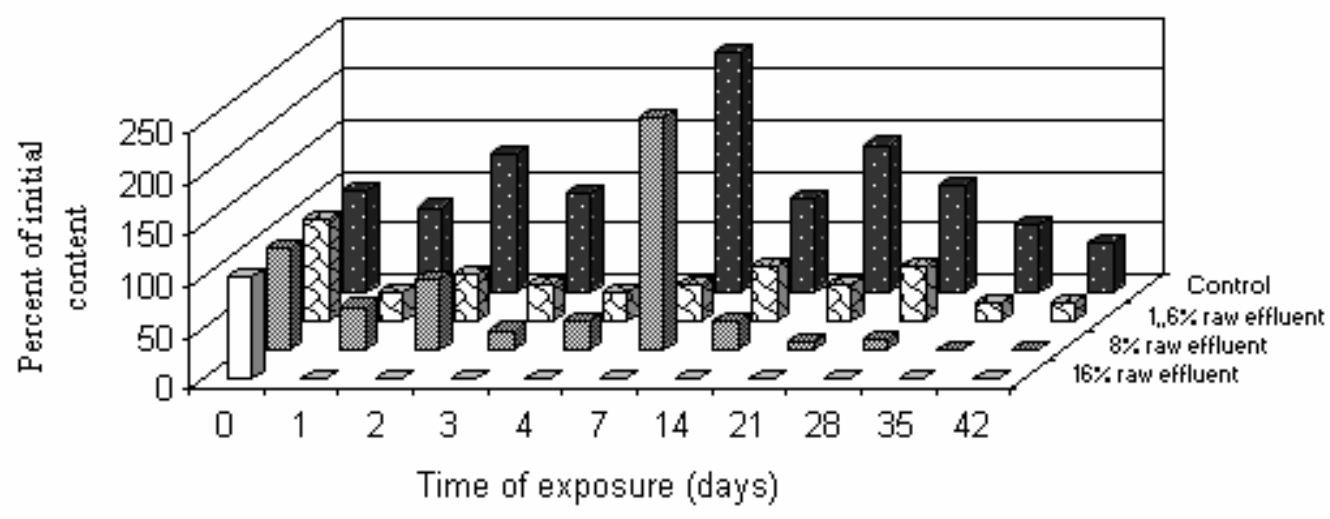

Annelids Tubifex $/ \mathrm{mL}$

Initial content: control $=575 ; 1.6 \%(\mathrm{VN})=25 ; 8 \%(\mathrm{~V} N)=116 ; 16 \%(\mathrm{VN})=127$

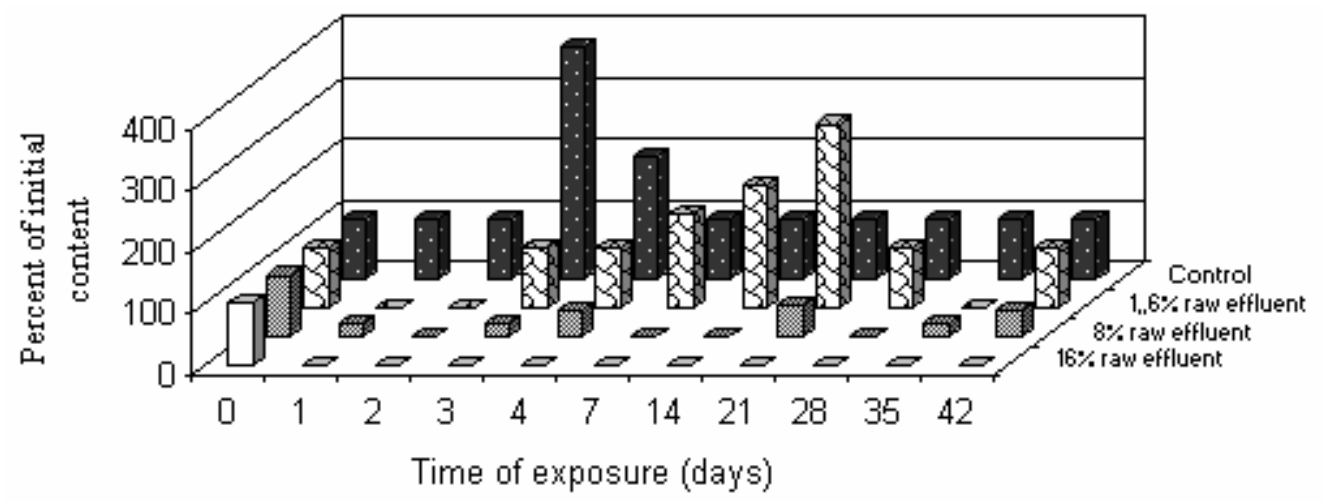

Planaria/mL

Initial content: control=100; $1.6 \%(\mathrm{VN})=10 ; 8 \%(\mathrm{VN})=46 ; 16 \%(\mathrm{~V} N)=340$

Figure 5: The effect of Pilcam effluent on benthic macro-invertebrates density of untreated and treated microcosms 


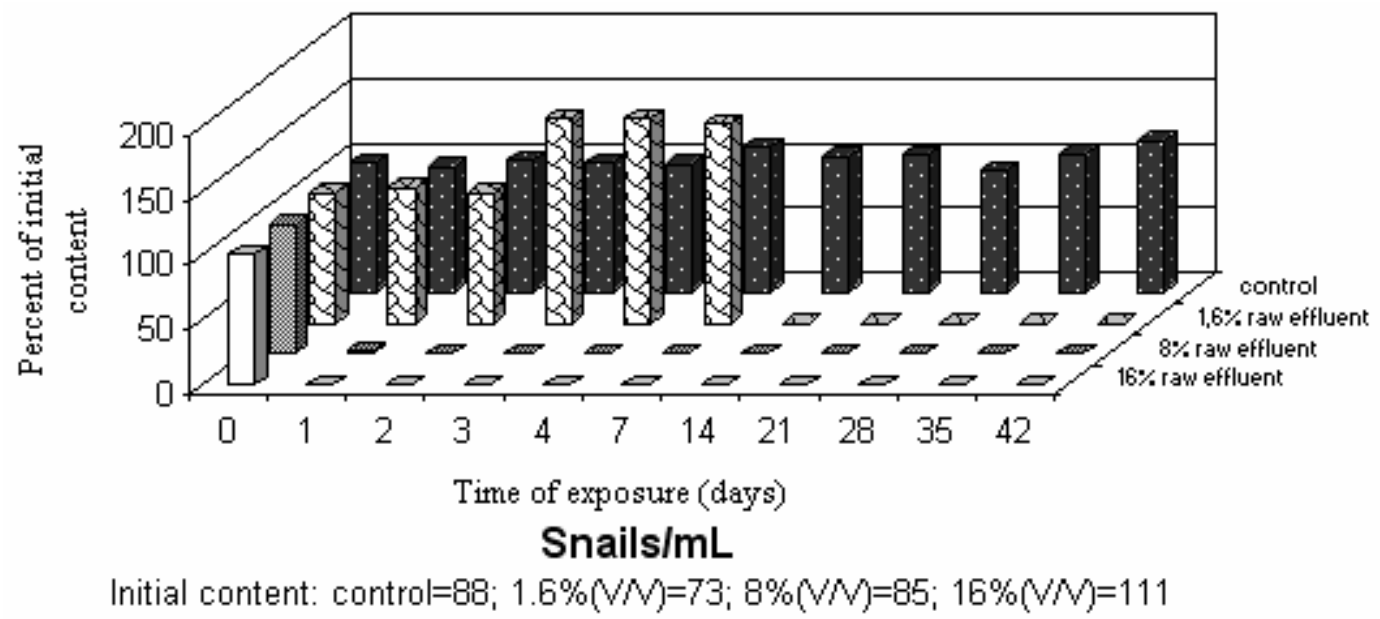

Figure 6: The effect of Pilcam effluent on aquatic snails' density of untreated and treated microcosms

microcosms and for short period of exposure in $8 \%$ and $16 \%(\mathrm{v} / \mathrm{v})$ microcosms were in order of decreasing sensitivity to the industrial effluent as follows: Strombidium gyrans $\rightarrow$ Disematostoma sp. $\rightarrow$ Coleps hirtus $\rightarrow$ Uronema sp.

\section{Effect of Pilcam Effluent on the Benthic Macro-} Invertebrates

The population dynamic of benthic macroinvertebrates under Pilcam effluent stress was similar to that of the protozoans. Their density in treated microcosms was in general reduced relative to the initial values after one day of exposure. The inhibitory effects of the industrial effluent at all sampling periods were most obvious for annelids whose biomass shifts followed a concentration-response pattern expected for single species tests and were significant in $8 \%$ and $16 \%(\mathrm{v} / \mathrm{v})$ microcosms (Fig. 5). These benthic organisms were eliminated from the $16 \%(\mathrm{v} / \mathrm{v})$ microcosm after one day of exposure. Snails were very sensitive to Pilcam effluent as they were all killed in $16 \%$ and $8 \%(\mathrm{v} / \mathrm{v})$ microcosms after one and two days of exposure respectively (Fig. 6). These invertebrates' organisms have been reported as being the first ones to be eliminated when the environment is saturated with heavy metals [3], especially with $\mathrm{Hg}$ and $\mathrm{Zn}$ that interfere with their respiratory function [8].

\section{Conclusions}

The addition of Pilcam effluent adversely affected the water quality of test microcosms by causing a significant increase in conductivity, salinity, and total hardness. Industrial effluent concentrations of $8 \%$ and $16 \%(\mathrm{v} / \mathrm{v})$ induced significant decreases in color, turbidity, total suspended solids, dissolved oxygen, and ammonia-N. All tested organisms, including fish, plankton, benthic macroinvertebrates and snails, were sensitive at various degrees to the industrial effluent, even at the lowest tested concentration of $1.6 \%$. Further studies are needed to determine the no observable adverse effect level (NOAEL), as well as a chronic reference concentration for this effluent.

Acknowledgements: This research was financially supported in part by the International Foundation for Science, Stockholm, Sweden, and the Organization for the Prohibition of Chemical Weapons, in the Hague, (the Netherlands), through a grant (No. C/2488-2) to Dr. Adolphe Monkiedje, in part by IRD AIRE Development Program through grant No. 01-02-CMR31-1 to "Equipe Hydrobiologie", and in part by "Fonds Universitaire d'Appui a la Recherche (FUAR)" of the University of Yaounde I, through a grant No. 99/5A7.

\section{References}

1. Dieter, H.; Manfred, H. : Actions de l'homme sur le paysage. In : Atlas de l'écologie. Dieter, H.; Manfred, H. (Eds.). (Eds.). Livre de poche: Paris, 1996, Chapter 7, pp. 198-208.

2. Connell, D. W. Water pollution. Causes and effects in Australia and New Zealand. $2^{\text {nd }}$ edition. University of Queensland Press: St Lucia, Old. 1981, pp. 169-192

3. Alabaster, J. S.; Llyod, R.: Water Quality Criteria for freshwater fish. FAO and Butterwotrhs: London, 1982, pp. 319-354.

4. Lorenz, S.; Francese, M., Smith, V. J.; Ferrero, E.A. Heavy metals affect the circulating haemocyte in the shrimps. Palaemon elegans, Fish Shellfish Immunol., 2001, 11, $459-472$.

5. Dejoux, C.: Les pollutions liees a l'essor démographique et économique de l'Afrique. In: La pollution des eaux continentales africaines : Expérience acquise, situation actuelle et perspectives. Orstom: Paris, 1988, pp. 458-484. 
6. Wattras, C. J.; Back, R. C.; Halvorsen, S.; Hudson, R. J.; Morrison, K. A.; Wente, S. P. : Bio-accumulation of mercury in pelagic freshwater good webs, Sci. Total. Environ. Contam. Toxicol, 1998, 19, 183-208.

7. Gray, J. S.: Biomagnification in marine systems: the perspective of an ecologist, Mar. Pollut. Bull., 2002, 45, $46-52$.

8. Spicer, J. I.; Weber, R. E.: Respiratory impairment in crustaceans and molluscs due to exposure to heavy metals, Comp. Biochem. Physiol., 1991, 100, 339-42.

9. Sama, D. A.: The Constraints in Managing the Pathways of Persistent Organic Pollutants into the Large Marine Ecosystem of the Gulf of Guinea-The Case of Cameroon. Intergovernmental Forum on Chemical Safety (WHO/IFCS), EXPERTS MEETING ON Persistent Organic Pollutants. 19 June 1996, Manila, Philippines.

10. Cairns, J. Jr.; Pratt, J. R.; Niederlehner, B. R.; McCormick, P. V.: A simple cost-effective multispecies toxicity test using organisms with a cosmopolitan distribution. Env. Monit. Assess. 1986, 6, 207-220.

11. Niederlehner, B. R.; Pratt, J. R.; Buikema, A. L. Jr. ; Cairns, J. Jr.: Laboratory tests evaluating the effects of cadmium on freshwater protozoan communities. Env. Toxic. chem. 1985, 4, 155-165.

12. Pratt, J. R.; Bowers, N; Niederlehner, B. R.; Cairns, J. Jr.: Effects of atrazine on freshwater microbial communities. Arch. Environ. Contam. Toxicol. 1988 17, 449-457.

13. Elder, J. F.; Collins, J. J.: Fresh water molluscs as indication of bio-availability and toxicity of metals in surface-water systems, Rev. Environ. Contam. Toxicol., 1991 122, 37 - 79.

14. Neveu, A.: Les invertébrés aquatiques, bioindicateurs de perturbations. In : L'eau dans l'espace rural : vie et milieux aquatiques. Neveu, A. ; Riou, C.; Bonhomme, R.; Chassin, P. ; Papy F. (Eds.). INRA Editions: Paris, 2001, pp. 175-196.

15. Wells, F.; Metzeling, L.; Newall, P.: Macroinvertebrates regionalization for use in the management of aquatic ecosystems in Victoria, Australia, Environ. Monit. Assess. 2002, 74, 271-74.

16. Monod, G.: Le poisson cible et révélateur de la pollution chimique. In : L'eau dans l'espace rural: vie et milieux aquatiques. Neveu, A.; Riou, C.; Bonhomme, R.; Chassin, P. ; Papy F. (Eds.). INRA Editions: Paris, 2001, pp. 135-156.

17. APHA (American Public Health Association). Standard Methods for the Examination of Water and Wastewater. $18^{\text {th }}$ Edition, APHA - AWWA. WPCF (eds), Washington D.C. 1998, 1268 p.

18. USEPA. Methods for Acute Toxicity Tests with Fish, Macro-invertebrates and Amphibians. Ecological Research Series. 1972, EPA/660/4-75/009.
19. Rausch, P.: The estimation of microalgae protein content and ist mining to the evaluation of algae biomass, v: comparison of methods for extraction protein, Hydrobiologia, 1981, 78, 237-251.

20. Bradford, M. A rapid and sensitive method for the quantification of microgram quantities of proteins, utilizing the principle of protein dye binding, Anal. Biochem. 1976, 72, 248-254.

21. Sayler, G.; Puziss, M.: Alkaline phosphatase assay for freshwater sediments: application to perturbed sediment system, Environ. Microbiol, 1979, 38, 922927.

22. Cairns, J. Jr.; Kuhn, D.; Plafkin, J.: Protozoan colonization of artificial substrates, In: Methods and Measurements of attached microcommunities. Weitzel, R. L. (Ed.). American Society for Testing and Materials: Philadelphia, 1979, pp. 39-54.

23. Kemka, N. Evaluation du degré de trophie du lac municipal de Yaoundé : Etude du milieu, dynamique et structure du peuplement phytoplanctonique. These de doctorat troisieme cycle, Universite de Yaounde I. 2000, $186 p$.

24. Anonymous. Metals. http://www.liv.ac.uk/ $\simeq$ preston/metals.htm 2004.

25. Onwumere, B. G.; Oladimeji, A. A.: Accumulation of metal and histopathology in Oreochromis niloticus exposed to treated NNPC Kaduna (Nigeria) petroleum refinery effluents, Ecotoxicol. Environ. Safety 1990, 19, 123-34.

26. Alam, K.; Maughan, M. O.; Van Ert, M. D.: Physicochemical characterization of industrial effluents and their effect on fish survival, Environ. Sci .Health., 1991, 26, 683-96.

27. Bu-olayan, A. H.; Al-Hassan, R.; Thomas, B. V.: Trace metal toxicity to phytoplankton of Kuwait coastal waters, Ecotoxicol., 2001, 10, 185 - 9 .

28. Stirling, H. P.: Chemical and biological methods of water analysis for aquaculturists. Institute of Aquaculture, University of Stirling, UK, 1985. 117p.

29. Sudhakar, G.; Jyothi, B.; Venkateswarlu, V.: Metal pollution and its impacts on algae in flowing waters in India, Arch. Environ. Contam. Toxicol, 1991, 21, 556-66.

30. Paerl, H. W.: Growth and reproductive strategies of freshwater blue-green algae (cyanobacteria). In: Growth and reproductive strategies of freshwater phytoplankton. Sandgren, C.D. (Ed). Cambridge University press: Cambridge, 1988, pp. 261-315.

31. Eva, W.; Gunnel, A.; Anna-Carin, S.: Toxic cyanophyta in three Swedish lakes, Verh. Interntl. Verein. Limnol. 2000, 27, 560-564.

32. Celia, L., Sant'Anna; Maria Theresa de Azevelo: Contribution to the knowledge of potentially toxic cyanobacteria from Brazil, nova hedwigia, 2000, 71, 359-385. 